\title{
EVALUATION OF THE APPLICABILITY OF STATISTICAL METHODS IN STUDIES ON PRICE DYNAMICS ON THE REAL ESTATE MARKET
}

\author{
Sebastian Kokot, Assoc. prof., Ph.D \\ Department of Econometrics and Statistics \\ Szczecin University \\ e-mail: sebastiankokot@o2.pl
}

Marcin Bas, M.Sc
ESTIT Marcin Bas
e-mail: m.bas@estit.pl

\begin{abstract}
The specific character of the real estate market is the reason why observations of transaction prices seen as statistical variables are taken in a non-standard way. In the traditional approach each time period or specific moments of time are attributed with one observation of a studied variable per one object. In the case of the real estate market, this is not possible since transactions relate to different objects, i.e., properties, and occur at irregular, or even random, moments. This is why traditional methods used to examine the dynamics of economic phenomena must be adapted to specific conditions on the real estate market. Keeping that in mind, the aim of this paper is to adapt classical statistical examination methods of dynamics to specific conditions of the real estate market followed by the actual examination of the dynamics of real estate prices in three sub-segments of the housing market in Szczecin. On its basis, the authors evaluate various methods of examining real estate price dynamics in terms of their applicability in real estate appraisal procedures and, in a broader perspective, present characteristic phenomena that can be observed on the real estate market.
\end{abstract}

Keywords: real estate market, prices, dynamics.

JEL Classification: R20.

Citation: Kokot S., Bas M., (2013), "Evaluation of the applicability of statistical methods in studies on price dynamics on the real estate market", Real Estate Management and Valuation, vol. 21, no. 1, pp. 49-58.

DOI: $10.2478 /$ remav-2013-0007.

\section{Introduction}

The specific character of the real estate market and the real estate itself, as the object of market turnover, have often been discussed in literature. However, the methods used to examine the price dynamics on this market are not a popular subject. Nevertheless, the authors consider it very important because transaction price correction is a vital element of real estate appraisal procedures. Its importance is reflected in legal regulations (REGULATION OF THE COUNCIL OF MINISTERS 2004) obliging appraisers to include it in their calculations. But, apart from legal obligations, careful observation of price movements on the real estate market can also be helpful in other areas of real estate management.

Because of the specific nature of the real estate market, it is not possible to construct price indices by means of methods that are also applied to determine other goods' indices (WoOD 2005). The indices used in practice reflect reality with varying precision (TROJANEK 2008, 2009, 2010). On the real estate 
market, the observations of transaction prices treated as statistical variables are conducted in a nonstandard way. In the classical approach, each period or a specific moment of time is attributed with one observation of an examined variable (e.g., company production in individual months or a company's debt at the end of each quarter, etc.). If we wanted to observe the real estate market in the same way, we would have to do it on a regular basis - for example, observe the transaction price of a particular property each month, which is obviously not possible. Transactions that are concluded on the market deal with different objects (properties) and occur at irregular, or even random moments (FORYŚ, KOKOT 2001), which means that we have to adjust traditional ways of analysing the dynamics of economic phenomena to the particular nature of the real estate market. This problem can be called technical, although it is not the only or the pivotal one. When dealing with real estate price dynamics the difficulties that we encounter are of a substantive nature. Generally speaking, these difficulties result from the bad quality of the available data, which, in turn, is the consequence of the scarcity of such transactions and of the heterogeneous nature of real properties being sold. Therefore, the observed price corrections can be triggered by two groups of factors:

1) random factors, i.e., the ones associated with the quality of properties being sold,

2) factors which reflect the actual situation on the real estate market.

\section{Research Methods}

From the point of view of market analyses, we should focus on identifying the price changes which have been initiated by the second group of the above mentioned factors. Unfortunately, it is extremely difficult for researchers to decide which price changes are the consequence of which group of factors. In this approach, random factors disturb the factual price trends. Therefore, the methods of examining price changes on the real estate market should be constructed in a way that helps to eliminate or at least minimise the impact of these factors.

Random factors can be eliminated in two ways:

1) mechanically - by interfering with the database of transactions and eliminating those transactions where prices differ significantly from the standard market price, or by the correction of transaction prices due to differences between individual properties and the standard property,

2) by seeking such a number of transactions in individual periods that would make them representative of the market. Because no researcher is able to control the number of transactions, the only way to do this is to prolong the period for which the average price is being determined.

The first way is difficult to apply in practice, since it requires the access to detailed information about the market prices of all sold properties. Additionally, there is the risk that the correction of transaction prices can be wrong. Finally, the whole process is very labour-intensive.

Having this in mind, the purpose of this article is to adapt classical methods of statistic examination of phenomena dynamics to the existing situation on the real estate market and, on this basis, to conduct research into the dynamics of property prices on the local real estate market in Szczecin. The research results will be used to evaluate various methods of examining the dynamics of real estate prices from a perspective of their applicability in appraisal procedures, as well as to learn more about the phenomena observed on the real estate market. In order to eliminate random factors, the authors attempt to make the market more representative by ensuring a satisfying number of transactions.

In order to generalise the conclusions, at least on the level of the housing market, the study has been conducted in three sub-segments:

1) The sub-segment of flats in pre-war multi-occupancy buildings that covers the whole city centre - Area 1

2) The sub-segment of flats in new multi-occupancy buildings constructed by real estate developers in the suburban districts of Osów and Warszewo - Area 2,

3) The sub-segment of owner-type cooperative flats in multi-occupancy buildings from the 1970s and 1980s located in the districts of Gumieńce, Krzekowo-Bezrzecze, Pogodno, Świerczewo, Pomorzany, Zawadzkiego - Area 3.

The authors apply two types of means - the arithmetic mean and the median, which gives the opportunity to evaluate these two measures in terms of their applicability in the analyses of real estate price changes. The arithmetic mean is a measure that is sensitive to extreme values, especially to 
outliers which can significantly distort its value as a measure of the average level of a given phenomenon. The median is free of such flaws and is thus recommended for testing the average level of phenomena characterised by irregular distributions, especially asymmetric ones. Due to the nature of the real estate market, we cannot expect its price distributions to be regular and, therefore, the median is considered more secure, i.e., more likely to accurately represent the average level of transaction prices.

\section{Empirical Material}

The authors used data containing the real prices of transactions between physical persons recorded in Szczecin in 2005-2012. When there were no transactions in a given month (this happened three times in Area 2), the mean value of the two neighbouring periods was adopted for that period. Table 1 shows the annual number of recorded transactions in the individual Areas.

Number of transactions in 2005-2012 in the individual Areas

Table 1

\begin{tabular}{lrrrrrrrr}
\hline & \multicolumn{8}{c}{ Year } \\
\cline { 2 - 9 } & 2005 & 2006 & 2007 & 2008 & 2009 & 2010 & 2011 & $2012^{*}$ \\
\hline Area 1 & 160 & 445 & 417 & 417 & 362 & 421 & 440 & 285 \\
\hline Area 2 & 15 & 90 & 161 & 140 & 217 & 284 & 237 & 120 \\
\hline Area 3 & 217 & 546 & 472 & 585 & 613 & 713 & 640 & 319 \\
\hline * to August 2012. & & & & & & & &
\end{tabular}

Source: Own database of transactions.

\section{Results and Discussion}

All the results of this study have been presented in graphs and evaluated visually. Graphs 1-3 show mean monthly prices in the above-mentioned areas. The monthly means are determined by a relatively small number of transactions, which consequently leads to the situation that their prices are accidental. An accident should be understood here as a quality structure of the turnover objects which is diversified and independent from the researcher. This structure has more impact on the obtained mean levels than the actual and objective market trends. In some months, no transactions whatsoever were recorded, which resulted in interpolation of the mean price. The dynamics curves are "jagged", which can lead to the conclusion that the presented mean price levels in the individual months measured by both the arithmetic mean and the median do not reflect the average market price well. The above situation can be observed in all the three sub-segments of the housing market. In some cases, the price fluctuations from month to month exceeded $20 \%$. Thus, it is obvious that, even on the well-developed market of a city with a population of 400,000, the monthly means are not representative features of transaction price levels and, therefore, cannot be used as a basis for transaction price corrections due to the flow of time in real estate appraisal procedures.

At the next stage of research, the authors determined linear trend functions based on the arithmetic means and medians. Because of the 2008 slump in the upward trend which had been observed until then, they outlined two functions covering the periods "before" and "after" the slump for each of the sub-segments by means of both the arithmetic means and medians. The results are presented in Graphs 4-6, while the calculated functions are described by Equations 1-12. All the calculated trend functions have significant structural parameters and some of them have high levels of the coefficient $\mathrm{R}^{2}$. Low levels of $\mathrm{R}^{2}$ in some functions, more specifically - in functions describing "the second" period in all the analyzed areas, result from the relatively big differences in the monthly mean transaction prices, while these prices, as has been shown above, reflect the qualitative structure of a property better than the real market trends. Despite of this, the visual analysis of the graph of these functions across empirical data raises doubts as to whether or not they show the market situation accurately, because there are periods when groups of subsequent observations appear at one side and then at the other side of the determined functions. This problem can be econometrically identified and eliminated by applying adequate statistical tests and by searching for better suited forms of trend analytical functions, but it would not lead to finding a solution that is universal in nature. What is more, the level of the numeric complication of such a procedure minimises its chance of becoming a popular appraisal tool, which has been the authors' research objective. Summing up this stage of the study, we 
can see that the estimation of linear trend functions is not a reliable formula for examining real estate price dynamics. It does not mean, however, that in some specific situations on local markets this method may not prove to be useful.

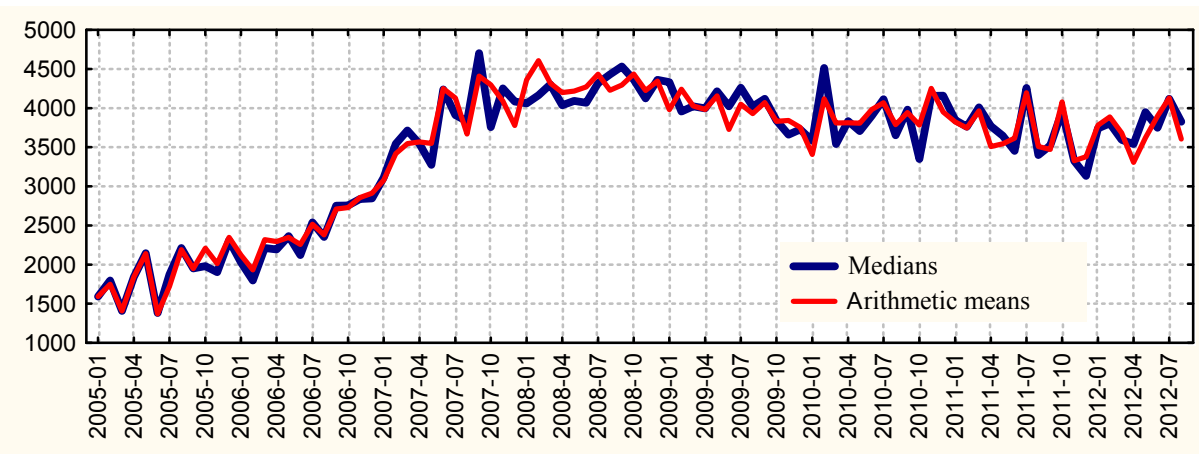

Graph 1. Monthly arithmetic means and medians determined for Area 1. Source: own study.

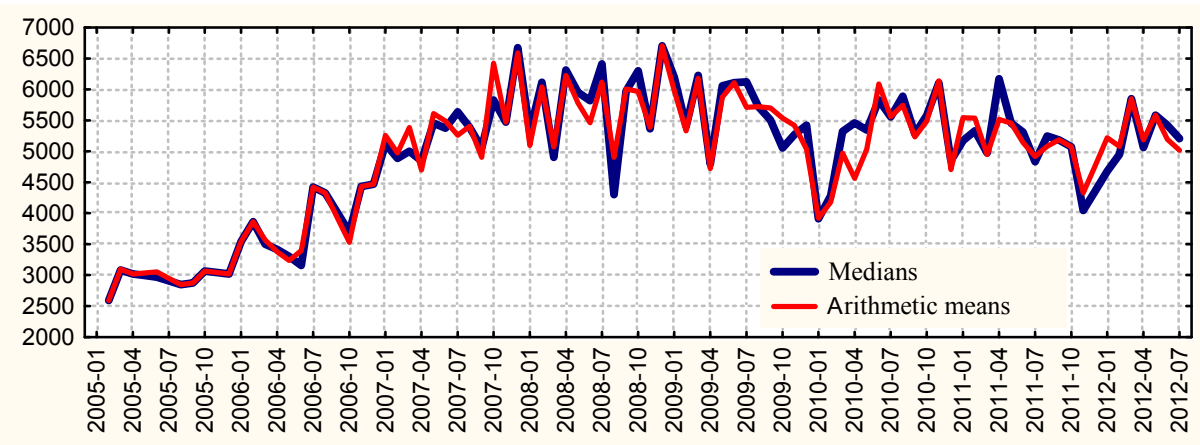

Graph 2. Monthly arithmetic means and medians determined for Area 2. Source: own study.

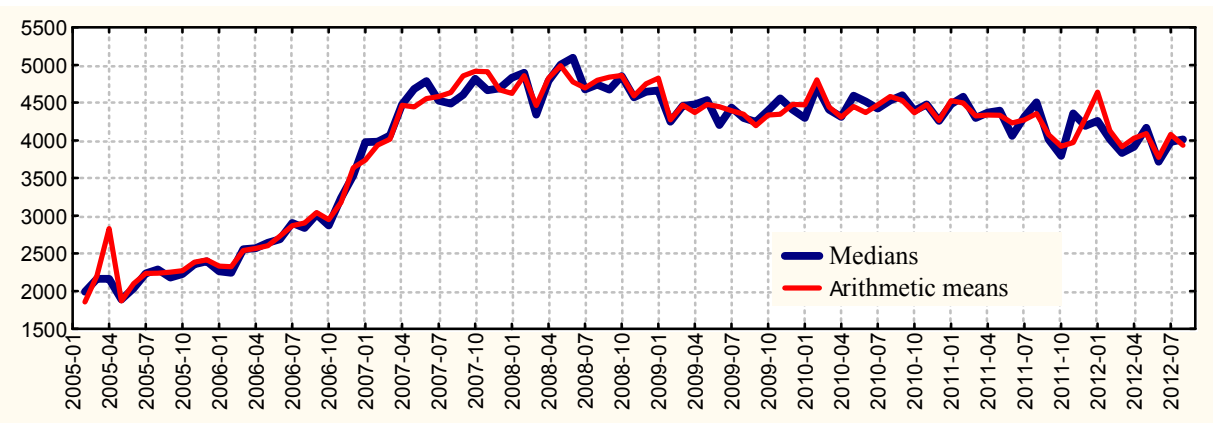

Graph 3. Monthly arithmetic means and medians determined for Area 3. Source: own study.

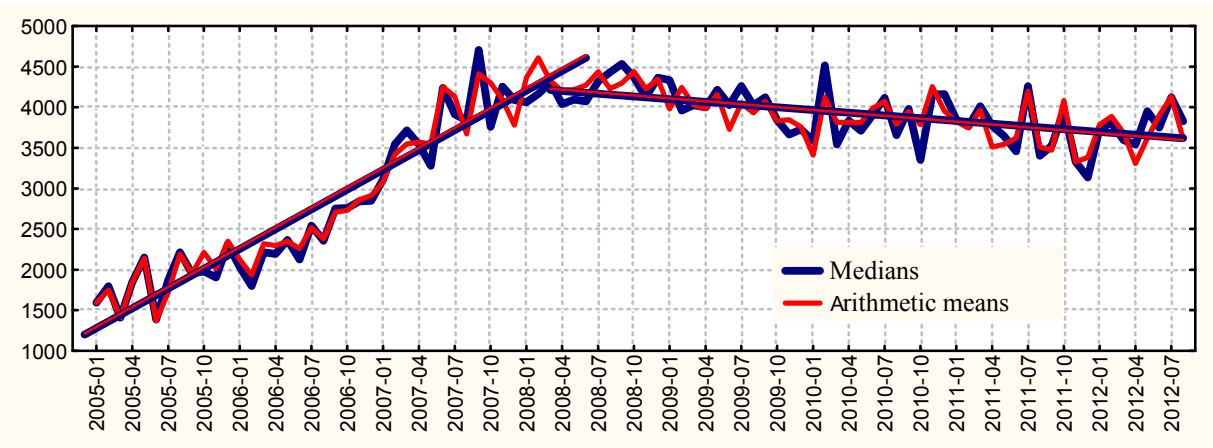


Graph 4. Monthly arithmetic means and medians with linear trend functions determined for Area 1. Source: own study.

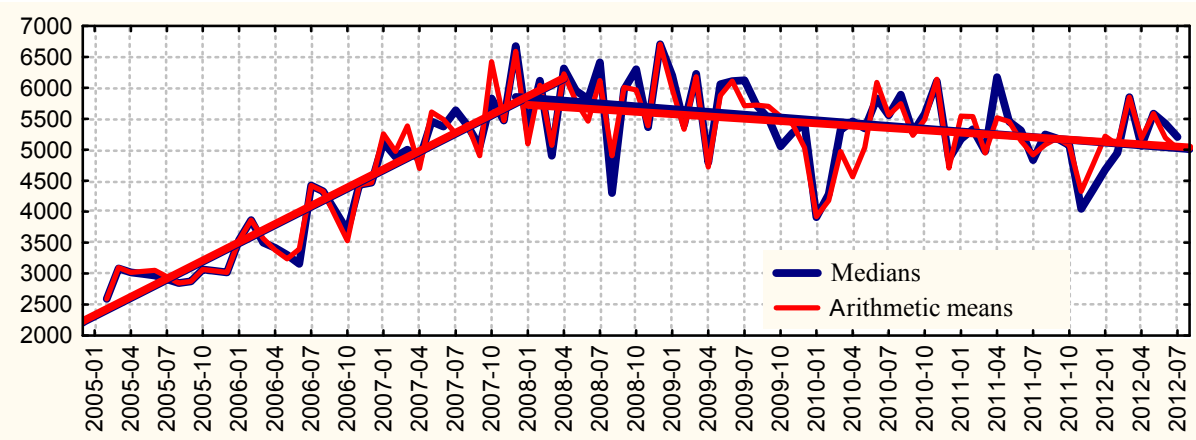

Graph 5. Monthly arithmetic means and medians with linear trend functions determined for Area 2. Source: own study.

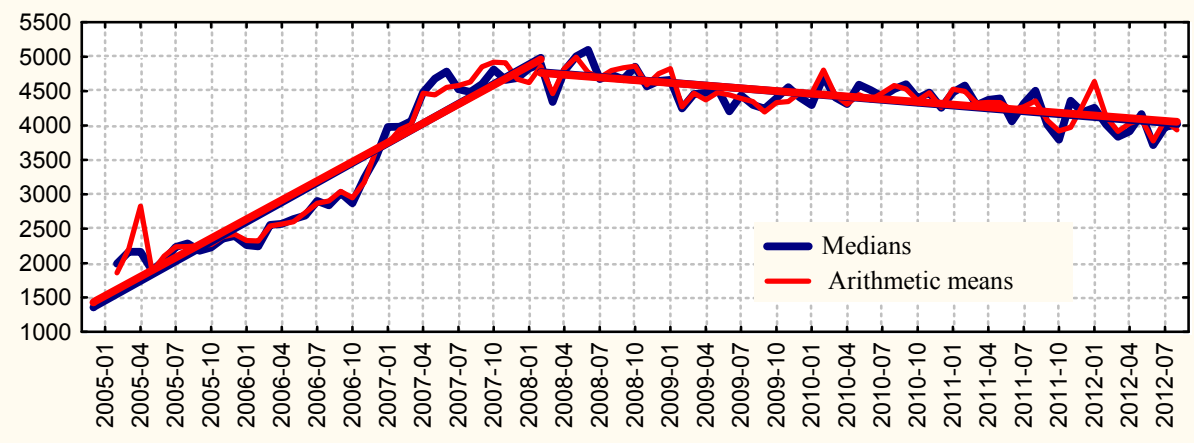

Graph 6. Monthly arithmetic means and medians with linear trend functions determined for Area 3. Source: own study.

$$
\begin{array}{rlr}
\hat{M}_{1}^{1}= & 1198.94+81.20 t & R^{2}=0.86 \\
& (115.49)(5.60) & \\
\hat{M}_{2}^{1}= & 4646.81-11.18 t & R^{2}=0.36 \\
& (131.15)(2.00) & \\
\hat{X}_{1}^{1}= & 1215.25+81.63 t & R^{2}=0.89 \\
& (101.24)(4.91) & \\
\hat{X}_{2}^{1}= & 4691.18-11.90 t & R^{2}=0.44 \\
& (118.18)(1.80) \\
\bar{M}_{1}^{2}= & 2209.93+98.38 t & \\
& (134.50)(6.09) & \\
\bar{M}_{2}^{2}= & 6396.41-15.07 t & R^{2}=0.88 \\
& (321.98)(4.88) & \\
\hat{X}_{1}^{2}= & 2230.39+98.29 t & R^{2}=0.85 \\
& (98.28)(7.02)
\end{array}
$$




$$
\begin{aligned}
& \widehat{X}_{2}^{2}=6186.96-12.46 t \quad R^{2}=0.13 \\
& \text { (291.45) (4.42) } \\
& \bar{M}_{1}^{3}=1357.63+95.45 t \quad R^{2}=0.91 \\
& \text { (111.42) (5.04) } \\
& \widehat{M}_{2}^{3}=5304.93-13.91 t \quad R^{2}=0.59 \\
& \text { (104.42) (1.57) } \\
& \hat{X}_{1}^{3}=1431.06+92.85 t \quad R^{2}=0.90 \\
& \text { (120.15) (5.44) } \\
& \widehat{X}_{2}^{3}=5365.66-13.18 t \quad R^{2}=0.61 \\
& \text { (96.13) (1.45) }
\end{aligned}
$$

Further in the study, the authors focus on increasing the representativeness of the sets of transaction prices in the individual periods for which the mean prices had been determined. Firstly, the authors lengthen the periods of study. The main disadvantage of this solution is a smaller number of results because of their scarcity. We can eliminate this problem by determining the mean values according to their proportionality, e.g., if the mean annual price in Year 1 is PLN 1,000 and in Year 2 PLN 1,120, then we can assume that it has grown evenly by PLN 10 every month. Another flaw of this method is that the division into sub-periods is made arbitrarily. In order to improve the clarity of results, the sub-periods usually cover three, six or twelve months. Yet, from the numeric point of view, this division can be made differently. For instance, the first half of a year can cover the time from October to March with the second half lasting from April to September. The question of how the means by which a period of the study is divided into sub-periods affects the study results can be the subject of a whole separate research thesis. The authors would just like to signal that although such a problem exists, they have based their study on the traditional division.

The periods for which the mean transaction prices have been determined are:

- three months (graphs 7-9),

- six months (graphs 10-12),

- twelve months (graphs 13-15).

The arithmetic means and medians of transaction prices in the individual quarters still display relatively big fluctuations from period to period, which means that the effect of random factors has yet not been eliminated and that their levels are still largely determined by the quality structure of the traded real estate. Hence, the conclusion that the quarterly means do not reflect the actual mean transaction prices and thus cannot serve as the basis for the examination of their dynamics can be drawn. A different conclusion comes from the observation of the half-yearly means where the impact of random factors is almost non-existent, the proof of which is the absence of significant differences from period to period - particularly in the case of the medians. Although, generally speaking, the graphs of the arithmetic means and the medians are similar, it turns out that in certain situations the median runs over the arithmetic mean, e.g., see Area 2 in the first six months of 2010. Therefore, it seems that the half-yearly averages, especially the medians, represent the market situation well and can be used to illustrate price dynamics. The average market transaction prices in the individual months can be determined according to the proportionality rule. Similar conclusions can be drawn while observing these measures on a yearly basis. In this case, the effect of randomness is practically eliminated and the average transaction prices can be determined by means of both the median and the arithmetic mean.

Another method of eliminating random factors is the determination of so called mechanically smoothed trends by means of moving averages. In this particular method the data regarding subsequent periods is replaced with the mean levels of a phenomenon in the examined periods and in several neighbouring periods (Statystyka 1996). For instance, triple periodic moving averages will be determined according to the following formulas:

$$
\bar{y}_{2}=\frac{y_{1}+y_{2}+y_{3}}{3}
$$




$$
\bar{y}_{3}=\frac{y_{2}+y_{3}+y_{4}}{3}
$$

etc. according to the rule:

$$
\bar{y}_{n-1}=\frac{y_{n-2}+y_{n-1}+y_{n}}{3}
$$

To make the calculations less complicated, the authors determine triple-periodic and septupleperiodic moving averages, which roughly corresponds to the adopted division into three- and sixmonth periods (moving averages with an even number of periods requires additional procedures centring). The results are presented in Graphs 16-18. When analysing their graphic presentation, we can see that, similarly to the arithmetic means and the quarterly medians, the triple-periodic moving averages do not eliminate random fluctuations. An additional flaw of this method is 'losing' observations from the initial and final period (Hozer et al. 2002). In this respect the septuple-periodic moving averages are more useful, but even this measure was sensitive to a sway near the beginning of 2010 which was observed in Area 2.

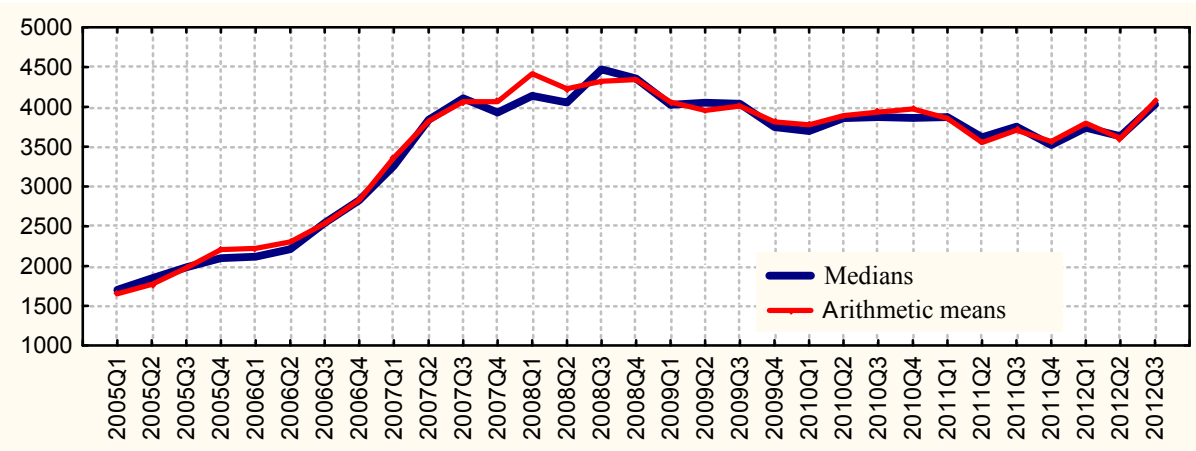

Graph 7. Quarterly arithmetic means and medians determined for Area 1. Source: own study.

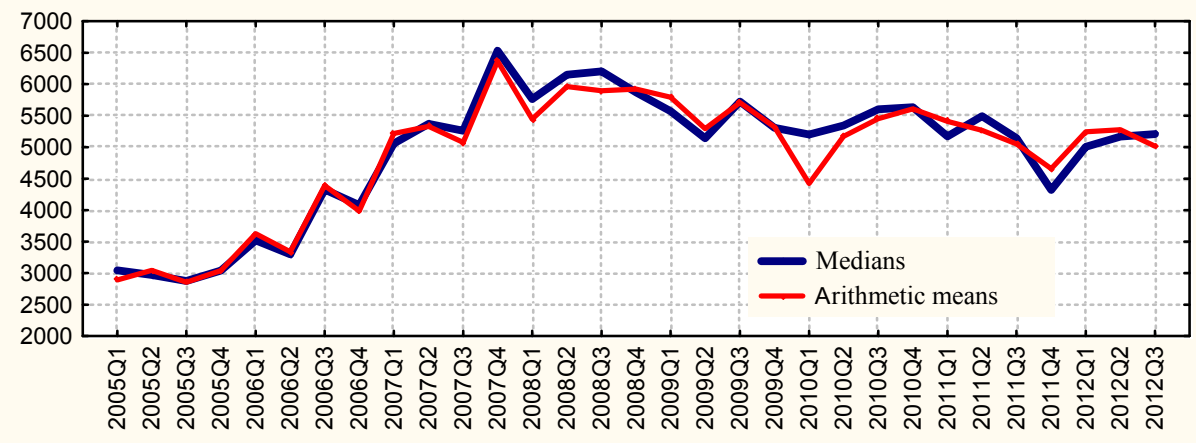

Graph 8. Quarterly arithmetic means and medians determined for Area 2. Source: own study.

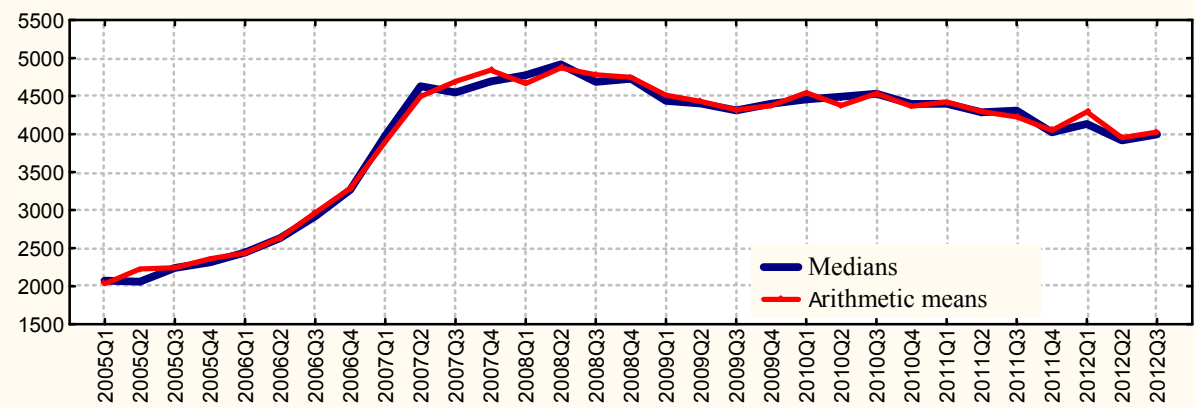

Graph 9. Quarterly arithmetic means and medians determined for Area 3. Source: own study. 


\section{VERSITA}

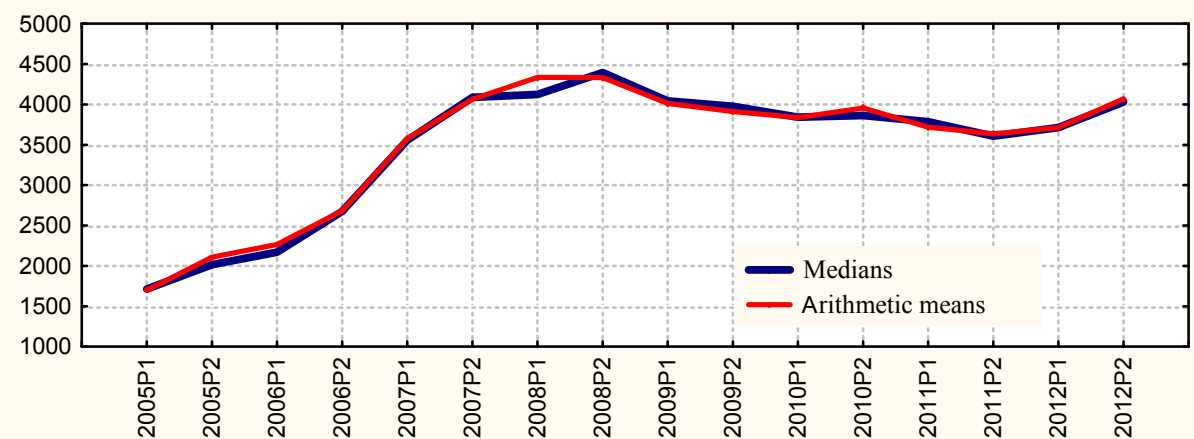

Graph 10. Half-yearly arithmetic means and medians determined for Area 1. Source: own study.

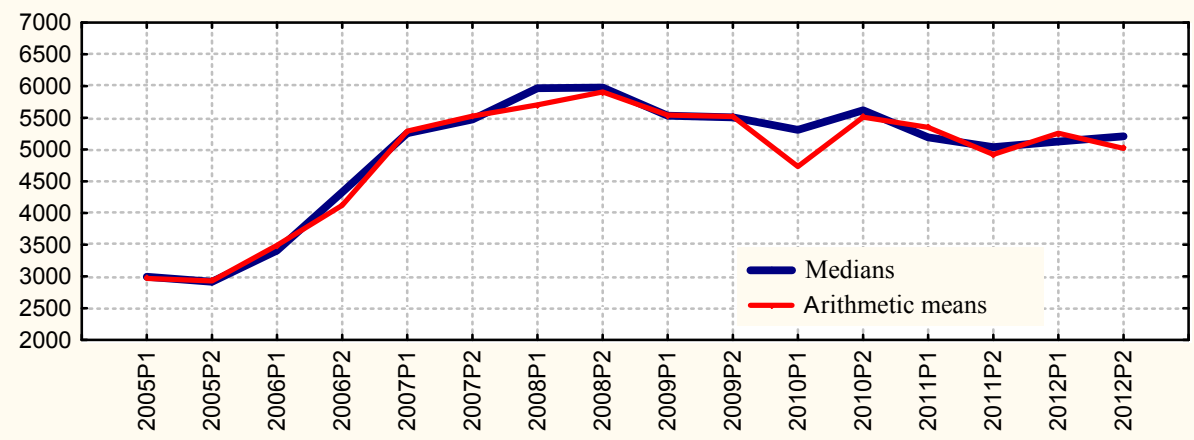

Graph 11. Half-yearly arithmetic means and medians determined for Area 2. Source: own study.

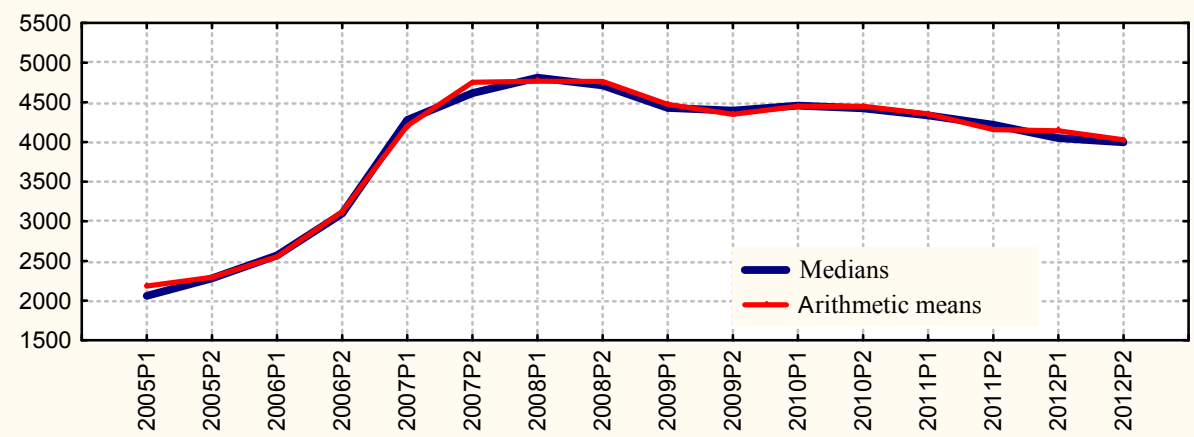

Graph 12. Half-yearly arithmetic means and medians determined for Area 3. Source: own study.

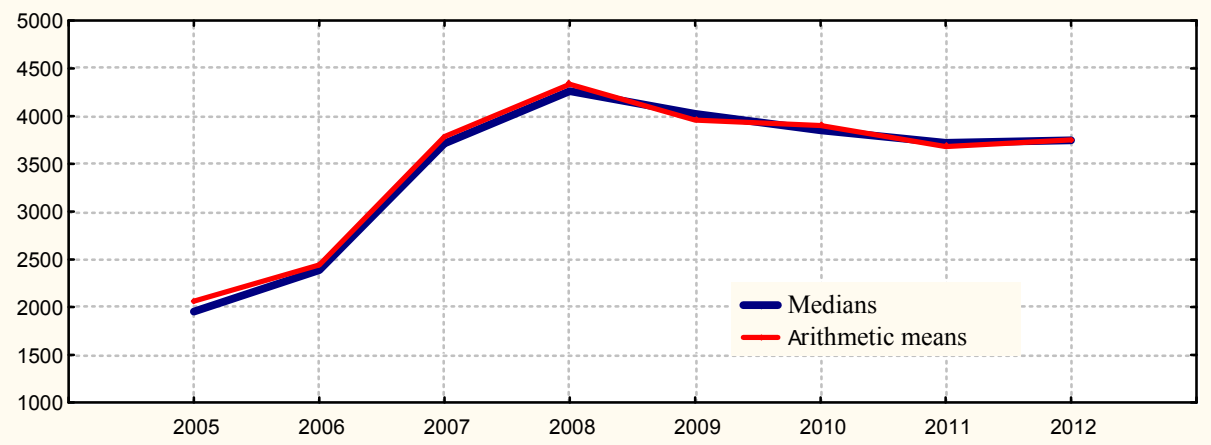

Graph 13. Yearly arithmetic means and medians determined for Area 1. Source: own study. 


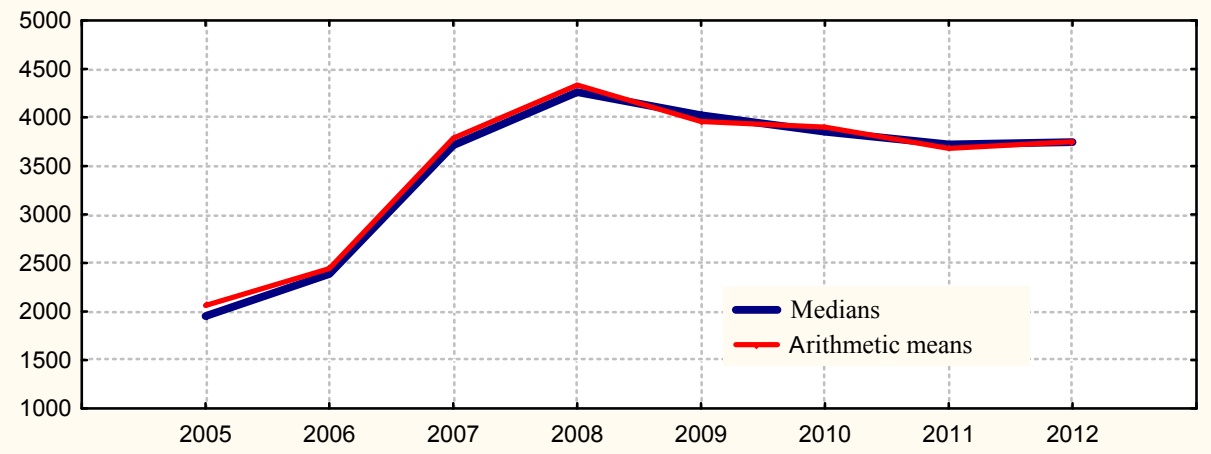

Graph 14. Yearly arithmetic means and medians determined for Area 2. Source: own study.

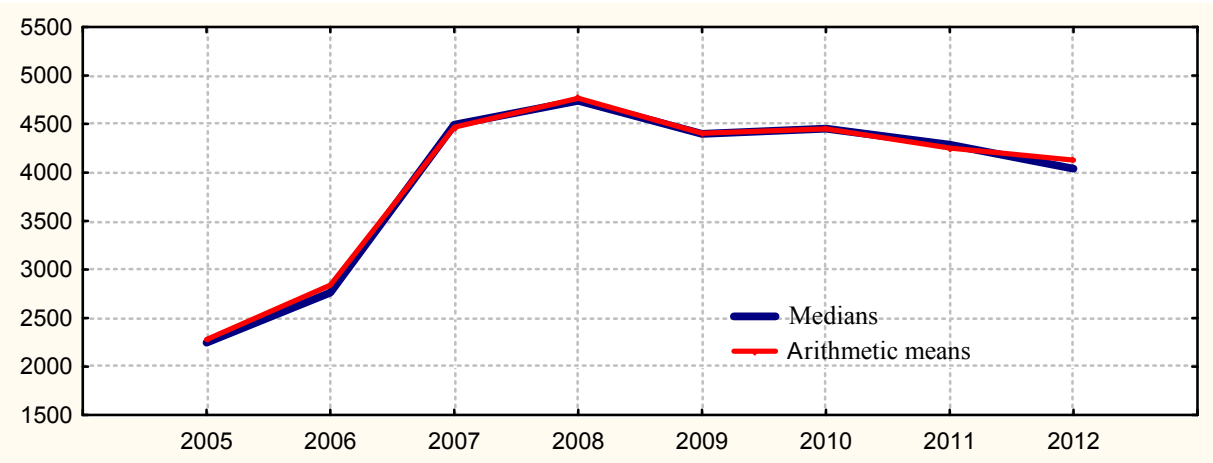

Graph 15. Yearly arithmetic means and medians determined for Area 3. Source: own study.

When summing up the outcomes of the study, the authors have come to the conclusion that the methods of examining the price dynamics on the real estate market in Szczecin which are most efficient in eliminating random fluctuations and, consequently, give the best grounds for determining price change indices are those where the means of longer periods are determined. The effect of eliminating these fluctuations has been obtained by using half-yearly and yearly arithmetical means. Keeping in mind that the periods of study should not be longer than the minimum necessary to eliminate random movements, the authors recommend the method based on the half-yearly medians as the most effective.

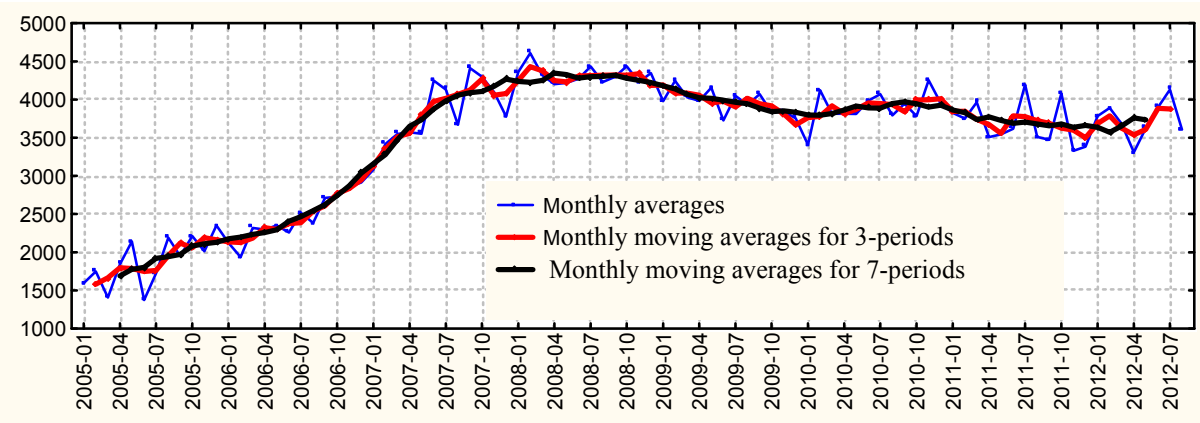

Graph 16. Monthly moving averages determined for Area 1. Source: own study. 


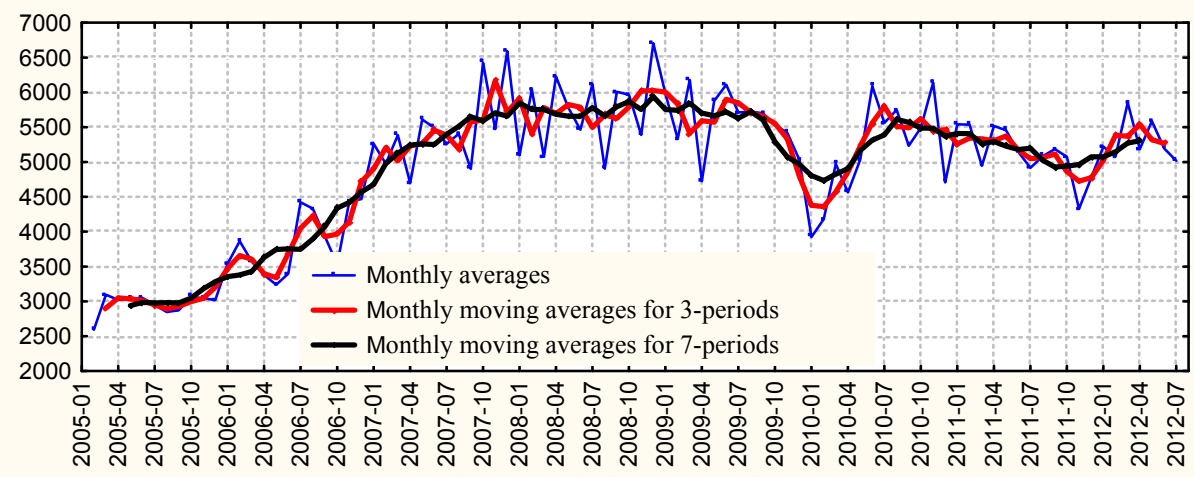

Graph 17. Monthly moving averages determined for Area 2. Source: own study.

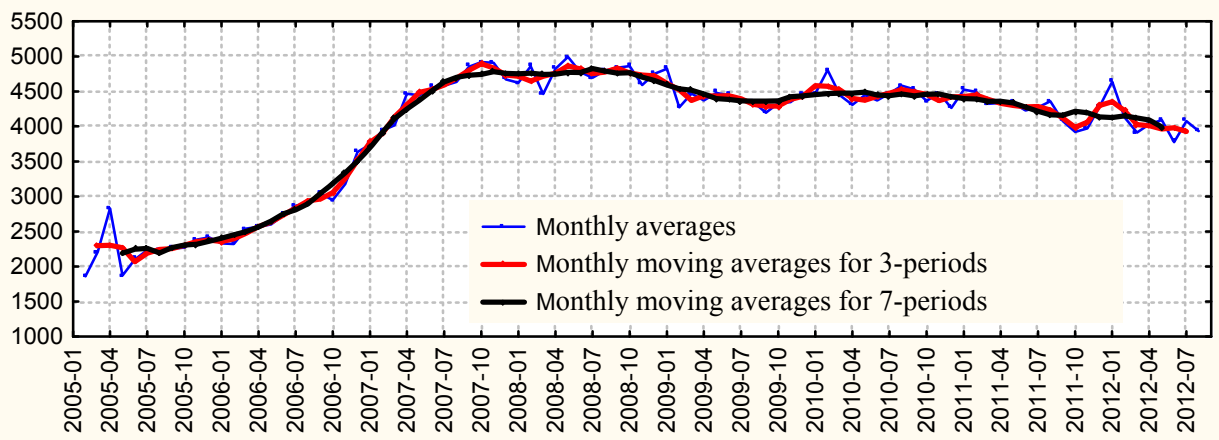

Graph 18. Monthly moving averages determined for Area 3. Source: own study.

It seems that the research that has been initiated by the present study is worth continuing and that it should be expanded in the following three directions:

1) finding and testing more methods,

2) finding formal procedures of evaluating the range of random movements to be eliminated by means of various methods of price dynamics examination,

3) initiating studies on various local markets and their segments.

In this context, the results of the present study should be regarded as a starting point for more indepth research.

\section{Bibliography}

FORYŚ I., KОКОт S., 2001, Problemy badania rynku nieruchomości, Zeszyty Naukowe US Nr 318, „Mikroekonometria w teorii i praktyce”, Prace Katedry Ekonometrii i Statystyki, Szczecin.

HOZER J., КОкOT S., KUŹMIŃSKI W, 2002, Metody analizy statystycznej rynku w wycenie nieruchomości. Polska Federacja Stowarzyszeń Rzeczoznawców Majątkowych, Warszawa.

Rozporządzenie Rady Ministrów z dnia 21 września 2004 r. w sprawie wyceny nieruchomości i sporządzania operatu szacunkowego.

Statystyka. Opis Statystyczny. (red. J. Hozer), 1996, Katedra Ekonometrii i Statystyki Uniwersytetu Szczecińskiego, Stowarzyszenie Pomoc i Rozwój, Szczecin.

TROJANEK R., 2008, Wahania cen na rynku mieszkaniowym, Wyd. Akademii Ekonomicznej w Poznaniu, Poznań.

TROJANEK R., 2009, Porównanie metody średniej oraz średniej ważonej do konstruowania indeksów cen nieruchomości mieszkaniowych, Studia i Materiały Towarzystwa Naukowego Nieruchomości, vol 17, no 2.

TROJANeK R., 2010, Porównanie metod prostych oraz regresji hedonicznej do konstruowania indeksów cen mieszkań, Studia i Materiały Towarzystwa Naukowego Nieruchomości, vol 18, no 1.

WoOD R., 2005, A Comparison of UK Residential Mouse Price Indices, BIS Paper, nr 21. 